\title{
PROPORCIONALIDADE IMPURA: 0 TRANSPLANTE DOS PRINCÍPIOS DA RAZOABILIDADE E DA PROPORCIONALIDADE À MODA BRASILEIRA
}

Luiz Henrique Urquhart Cademartori

Possui Pós-Doutorado em Filosofia do Direito pela Universidade de Granada (Espanha). Doutor em Direito do Estado e Mestre em Instituições Jurídico-políticas pela Universidade Federal de Santa Catarina (UFSC). Professor da Universidade Federal de Santa Catarina (UFSC) nos cursos de Graduação e Pós-Graduação. E-mail: luiz.cademartori@gmail.com

\section{Eduardo de Carvalho RêGo}

Doutorando em Direito, Política e Sociedade e Mestre em Teoria, História e Filosofia do Direito pela Universidade Federal de Santa Catarina (UFSC). Professor de Filosofia do Direito no Complexo de Ensino Superior de Santa Catarina (CESUSC). E-mail: eduardorego@gmail.com

\section{Resumo}

Razoabilidade e proporcionalidade são conceitos jurídicos historicamente desenvolvidos nos Estados Unidos da América e na Alemanha, respectivamente. No Brasil, ambos os institutos foram importados e incorporados ao ordenamento sob a denominação majoritária de princípio da proporcionalidade. Não sendo necessariamente sinônimos, a condensaçấo da razoabilidade e da proporcionalidade em apenas um postulado certamente traz problemas ao intérprete e ao aplicador da lei. Para piorar, e utilizando a ideia de "transplante jurídico" desenvolvida pelo jurista colombiano Diego López Medina em sua Teoría Impura del Derecho, o transplante descontextualizado dos institutos desenvolvidos nos "sítios de produção" norte-americano e alemão acabou dando origem, em terras brasileiras, a uma espécie de proporcionalidade impura, que ignora quase completamente o contexto histórico e jurídico por trás dos institutos em que buscou inspiração. Simplesmente congregando a "fórmula mágica" (adequaçáo, necessidade e proporcionalidade em sentido estrito) desenvolvida pelo Direito alemão com a noçấo de "bom senso" e "justa medida” consagrada no Direito anglo-saxão, criou-se no Brasil o princípio constitucional implícito da proporcionalidade. Como efeito de sua rápida popularização entre os juristas, o princípio acabou se tornando uma espécie de panaceia - remédio contra todos os males jurídicos - a ser utilizada pelo poder Judiciário brasileiro sobretudo contra as normas 
jurídicas produzidas pelo poder Legislativo e que sejam consideradas inoportunas ou inconvenientes: na verdade, com a proporcionalidade, o controle de constitucionalidade de normas ficou relegado ao alvedrio do Supremo Tribunal Federal e demais magistrados de níveis inferiores.

\section{Palavras-chave}

Proporcionalidade; Razoabilidade; Transplante; Teoria impura do Direito; Controle de constitucionalidade.

\section{Resumen}

Razonabilidad y proporcionalidad son conceptos jurídicos desarrollados históricamente en los Estados Unidos y Alemania, respectivamente. En Brasil, los dos institutos fueron importados e incorporados al sistema jurídico con la denominación mayoritaria de principio de proporcionalidad. No necesariamente sinónimos, la condensación de razonabilidad y proporcionalidad en tan sólo un postulado jurídico sin duda trae problemas al intérprete y el agente de la ley. Para empeorar las cosas, y utilizando la idea de "trasplante jurídico" desarrollada por el jurista colombiano Diego López Medina en su Teoría Impura del Derecho, el trasplante descontextualizado de los institutos desarrollados en los "centros de producción" estadounidenses y alemanes terminaron por dar a luz, en suelo brasileńo, una especie de proporcionalidad impura, ignorando casi por completo el contexto histórico y legal detrás de las instituciones que se inspiraron. Simplemente usando la "fórmula mágica" (idoneidad, necesidad y proporcionalidad en sentido estricto), desarrollada por el derecho alemán con la noción de "sentido común” y “justa medida” consagrada en el derecho anglosajón, se creó en Brasil el principio constitucional implícito de proporcionalidad. Como efecto de su rápida popularización entre los abogados, el principio resultó ser una especie de panacea - remedio contra todos los problemas legales - para ser utilizado por la justicia brasileńa en especial contra las normas legales producidas por la legislatura, que se consideran inconvenientes: en efecto, con la proporcionalidad, el control de constitucionalidad fue relegado a la discreción de la Corte Suprema brasileña y demás jueces de los niveles más bajos.

\section{Palabras clave}

Proporcionalidad; Razonabilidad; Trasplante; Teoría impura del Derecho; Control de constitucionalidad.

\section{Introdução}

Protagonista do ordenamento jurídico de uma nação, a constituição pode ser definida, sob um certo ponto de vista, como o conjunto de normas (regras e princípios) 
norteadoras das atividades dos poderes Executivo, Legislativo e Judiciário. No Estado Democrático de Direito, tudo se faz a partir da constituição e absolutamente nada contra ela. Tanto é assim que o constitucionalismo moderno consagrou em seu favor um relevante instrumento garantidor de sua supremacia: o controle de constitucionalidade de normas.

É célebre a discussão travada entre Hans Kelsen e Carl Schmitt sobre quem deveria ser o legítimo guardião da constituição. Para Kelsen, o controle de constitucionalidade de normas deveria ser exercido por um tribunal constitucional, órgão independente do Parlamento, eis que não faria sentido o próprio órgão criador do ato tido por irregular ser o juiz de sua compatibilidade com a constituição (KELSEN, 2003, p. 150). Já Carl Schmitt entendia que o legítimo guardião da constituição deveria ser o chefe do poder Executivo, único detentor do chamado "poder neutro", que lhe conferia não apenas a atribuição de proteger o Reich, como também a de defender a constituição (SCHMITT, 2007, p. 193-205).

Ao longo da história, a tese defendida por Hans Kelsen obteve maior sucesso, na medida em que, na grande maioria das democracias modernas, não se discute que o controle de constitucionalidade de normas é jurisdicional.

Por sinal, foi nos Estados Unidos da América que o controle jurisdicional de constitucionalidade de normas apareceu pela primeira vez, no célebre caso Marbury vs. Madison, decidido pela Suprema Corte norte-americana no início do século XIX. Foi também nesse mesmo país que o princípio da razoabilidade se originou (a partir da cláusula do substantive due process of law) e se consolidou como parâmetro de controle da constitucionalidade de normas e demais atos jurídicos do poder público.

A razoabilidade norte-americana serviu para combater leis editadas pelo poder Legislativo estadunidense em detrimento das liberdades pessoais (de expressão, de religiáo, de privacidade, etc.), garantindo às minorias direitos básicos não necessariamente positivados (escritos) na Constituição.

Outro marco importante no constitucionalismo moderno foi a "descoberta" do princípio da proporcionalidade pelo Tribunal Constitucional alemão. Fundamentado na necessidade de combater o chamado "excesso de poder legislativo", o princípio da proporcionalidade foi também tratado pelo Direito alemão como parâmetro de controle de constitucionalidade dos atos e normas jurídicas.

A fórmula da proporcionalidade (necessidade, adequação e proporcionalidade em sentido estrito) foi utilizada, sobretudo, para combater as leis nazistas subsistentes no ordenamento jurídico alemão no segundo pós-guerra.

É perceptível que o desenvolvimento dos princípios da razoabilidade e da proporcionalidade se deu em contextos bastante específicos, em que os Tribunais norte-americano e alemão, respectivamente, necessitavam agir em prol de determinados valores que eram 
importantes para a sociedade da época, mas que haviam caído no esquecimento dos legisladores.

Ocorre que, ao importar tais institutos jurídicos, o Direito brasileiro desconsiderou o contexto em que eles foram produzidos, realizando algumas simplificaçóes que verdadeiramente desnaturaram a razoabilidade e a proporcionalidade, convertendo-as, ademais, em simples instrumentos de poder em prol do Judiciário em sua constante tensão com os outros poderes.

O jusfilósofo colombiano Diego Eduardo López Medina explica que a importação de teorias norte-americanas e europeias é corrente na América Latina, salientando, ainda, que distorçóes como a acima citada sáo bastante comuns, a ponto de configurar uma espécie de tradição latino-americana: mais do que equívoco, as leituras atravessadas de teorias jurídicas estrangeiras sempre representaram a intenção dos países mais pobres de reinventar e/ou adaptar institutos jurídicos alienígenas às necessidades de naçóes em desenvolvimento.

Em síntese, o que se pretende demonstrar no presente trabalho é que o princípio brasileiro da proporcionalidade pouco tem a ver com a razoabilidade norte-americana ou mesmo com a proporcionalidade alemá: os juristas brasileiros manipularam esses institutos estrangeiros - criados num determinado contexto e para atender a uma determinada demanda - não necessariamente para conferir direitos ou garantir a supremacia da constituição, mas, sim, para simplificar o controle de constitucionalidade de normas e aumentar a subjetividade do julgador em temas que a Constituição reservou inicialmente ao Parlamento ou aos órgãos ligados ao poder Executivo. Assim é que, aplicando a "fórmula mágica" da proporcionalidade, o julgador legitima a sua ingerência em temas que constitucionalmente não seriam de sua alçada.

\section{Por uma Leitura Contextualizada dos Institutos Jurídicos}

É preciso conhecer a história por trás dos institutos jurídicos para poder entendê-los plenamente, em toda a sua extensão e complexidade. Não subsiste mais a clássica noção kelseniana de que o objeto de preocupação do jurista deva ser apenas o Direito formalmente positivado, aquele que é dado ou conferido pelo legislador aos cidadãos. Nesse sentido, não é demasiado afirmar que a boa interpretação jurídica não prescinde da necessária avaliação factual ou concreta das circunstâncias sociais que circundam um caso em apreço, como dado determinante na aplicação substancial dos direitos.

Não é possível falar de propriedade privada no Brasil, por exemplo, sem levar em consideração os processos de discussão ideológica e política que circundaram a tomada de decisóes em torno do tema, assim como não é possível ignorar o contexto fático em que 
se operou a adaptação do conceito para a noção de função social da propriedade privada, tal como prevista na Constituição Federal de 1988.

De igual modo, não se pode falar de direitos humanos como um a priori naturalmente existente, algo como uma dádiva conferida de pronto aos seres humanos, ignorando-se as incessantes lutas sociais por trás das conquistas de direitos. Como ressalta Joaquín Herrera Flores, "falar de direitos humanos é falar da abertura de processos de luta pela dignidade humana" (FLORES, 2009, p. 27).

O presente capítulo pretende analisar, ainda que brevemente, o contexto por trás da criação e difusão de dois dos princípios jurídicos jusfundamentais mais importantes para o Direito: o princípio da razoabilidade, desenvolvido nos Estados Unidos da América, e o princípio da proporcionalidade, desenvolvido na Alemanha. O objetivo é vincular a sua ascensão e consolidação à realidade vivenciada à época em seus países de origem. Abordar quais as lutas sociais estavam em pauta no momento em que o Estado, por meio do Judiciário, resolveu interceder nas disputas, utilizando-se de mecanismos até então desconhecidos no mundo jurídico para fazer preponderar a ideia de justiça sobre a ideia de mera legalidade. Como se verá, razoabilidade e proporcionalidade foram produtos de necessidades específicas vivenciadas pela sociedade norte-americana e alemá dos séculos XIX e XX.

\subsection{O Princípio Norte-Americano da Razoabilidade}

O princípio da razoabilidade foi originado e desenvolvido nos Estados Unidos da América. Os estudiosos relacionam sua origem à cláusula do due process of law, esta última originária da Inglaterra. Na dicção de Dirley da Cunha Júnior,

[...] a razoabilidade tem sua origem e desenvolvimento ligados à garantia do devido processo legal, antigo instituto do direito anglo-saxão, que remonta à cláusula law of the land inscrita na Magna Carta de 1215. Esta garantia teve origem na Inglaterra, com um aspecto meramente formal ("procedural due process", segundo o qual não é possível a condenação de alguém sem o devido processo legal) e se desenvolveu nos Estados Unidos com um aspecto muito mais substantivo ou material ("substantive due process of law"), para permitir ao Judiciário investigar o próprio mérito dos atos do poder público, a fim de verificar se esses atos são razoáveis, ou seja, se estão conforme a razão, supondo equilíbrio, moderação e harmonia (CUNHA JÚNIOR, 2008, p. 221).

A transição do procedural due process - que buscava apenas garantir a marcha processual de acordo com as formas prescritas em lei, sem analisar o conteúdo em si dos atos produzidos pelo poder público - para o substantive due process of law - que buscou empreender análise de validade acerca da substância, isto é, do próprio mérito dos atos 
jurídicos estatais - foi decisiva para a consolidação do princípio da razoabilidade no Direito norte-americano. Nessa mesma linha de raciocínio, Luís Roberto Barroso assevera que,

De fato, ao lado do princípio da igualdade perante a lei, essa versão substantiva do devido processo legal tornou-se importante instrumento de defesa dos direitos individuais, ensejando o controle do arbítrio do Legislativo e da discricionariedade governamental. É por seu intermédio que se procede ao exame de razoabilidade (reasonableness) e de racionalidade (racionality) das normas jurídicas e dos atos do Poder Público em geral (BARROSO, 2008, p. 219).

Nos Estados Unidos, essa análise sobre a razoabilidade ou racionalidade das normas e dos atos jurídicos produzidos pelo poder público sempre foi realizada sem maiores critérios de avaliação pré-definidos. Ou seja, nunca houve uma fórmula pré-concebida a fim de auxiliar o intérprete ou o julgador na aferição da razoabilidade. A bem da verdade, o parâmetro para se medir a razoabilidade ou desarrazoabilidade de um ato estatal sempre foi a ideia comum de "bom senso", "justa medida", enfim, de "justiça". Nesse mesmo sentido, Barroso assenta que, no contexto jurídico norte-americano, "O princípio da razoabilidade é um parâmetro de valoração dos atos do Poder Público para se aferir se eles estão informados pelo valor superior inerente a todo ordenamento jurídico: a justiça” (BARROSO, 2008, p. 224).

Muitas vezes tendo como pano de fundo a cláusula do devido processo legal, a Suprema Corte norte-americana adentrou em discussôes anteriormente relegadas ao poder Legislativo estadunidense. Fábio de Oliveira destaca:

Em Mugler v. Kansas (1877), a Corte indica fronteiras que devem ser cumpridas pela legislação sob pena de invalidação jurisdicional: relação conduta/fim e direitos fundamentais. No caso Allegeyer $v$. Louisiana (1897), o órgão de cúpula do Judiciário estadunidense, pela primeira vez, nulifica uma lei com base no devido processo e, assim, consagra a tomada da versão material da cláusula. Os estudiosos indicam o litígio entre Lochner v. New York (1905) como um símbolo deste período: a Suprema Corte decide ser inconstitucional lei que estipula a jornada máxima de trabalho em dez horas por dia (sessenta por semana) para os padeiros, pois tal norma vai de encontro com a considerada liberdade contratual entre empregador e empregado (OLIVEIRA, 2007, p. 84).

Como se vê, a razoabilidade norte-americana foi avançando de acordo com as demandas sociais que iam sendo levadas à Suprema Corte. Foi ali que a cláusula do devido processo legal substancial foi se convertendo, aos poucos, em aferição de razoabilidade de leis e atos jurídicos produzidos pelo Estado. Foi por essa via, da razoabilidade, que o Judiciário foi pautando a agenda política da nação, o que acabou por garantir a ele, em última análise, um certo protagonismo na tensão entre os poderes instituídos. 
Luís Roberto Barroso exemplifica esse movimento do Judiciário norte-americano com os seguintes casos:

No âmbito da aplicação substantiva do devido processo legal, os casos que mais destacadamente marcaram época, pela ousadia, foram Griswold vs. Connecticut e Roe vs. Wade, onde a Suprema Corte declarou a inconstitucionalidade de leis estaduais e consagrou um novo direito, não expressamente inscrito na Constituiçáo, que foi o direito de privacidade. Em Griswold, invalidou-se uma lei do Estado de Connecticut que incriminava o uso de pílula anticoncepcional ou qualquer outro artigo ou instrumento contraceptivo, punindo tanto quem consumisse como quem prescrevesse. Em Roe, a Corte considerou inconstitucional uma lei do Texas que criminalizava o aborto, e náo admitia nem mesmo antes do terceiro mês de gravidez (BARROSO, 2008, p. 222-223).

A Constituição norte-americana data de 1787, permanecendo em seus termos iniciais ainda hoje, com pouquíssimas emendas. Parece natural que, conforme a sociedade e seus anseios foram avançando, o Judiciário (aplicador da lei) tenha tido de reinventar a si mesmo e a própria constituição.

$\mathrm{O}$ que se quer dizer é que o movimento da sociedade norte-americana fez com que o Judiciário tivesse de intervir em algumas questóes nevrálgicas da democracia dos Estados Unidos, sob pena de distanciar-se da vida real, relegando suas decisóes ao plano teórico, sem qualquer possibilidade de adesão prática. Por exemplo: a decisão que declarou inconstitucional, por desarrazoada, a prescrição e o uso de pílulas anticoncepcionais certamente passou pela ponderação de que o Direito não poderia pretender criminalizar uma conduta amplamente praticada na sociedade.

Assim, a elaboração do princípio da razoabilidade - ou sua concepção hermenêutica de princípio constitucional implícito - visou atender a essa necessidade norte-americana de oxigenação de interpretaçóes jurídicas estritamente formais sem o gravame de romper com a ordem constitucional vigente. Em suma, com a razoabilidade, o Judiciário dos Estados Unidos viu-se legitimado a expurgar do ordenamento jurídico normas consideradas injustas pela sociedade.

\subsection{Princípio Alemão da Proporcionalidade}

Pode-se dizer que o princípio da proporcionalidade foi desenvolvido na Alemanha em paralelo à ideia norte-americana de razoabilidade. Fábio de Oliveira explica que a noção do princípio "surge na Europa continental ligado à teoria do desvio de poder (détournement de pouvoir) por obra do Conselho de Estado da França (Conséil D'État)" (OLIVEIRA, 2007, p. 87). Porém, embora a teoria do desvio de poder tenha surgido na 
França, não se pode negar que foi na Alemanha que a proporcionalidade ganhou seus contornos decisivos, convertendo-se verdadeiramente num princípio jurídico autônomo, conforme salientado por Leonardo Luiz Passafaro Júnior:

O princípio da proibição do excesso, ou da proporcionalidade, na sua feição atual, remonta-se ao último quarto do século XX. As idéias mais ou menos dispersas de proporção, de aversão pelo excesso, ou de necessidade encontram-se subjacente a ele, posto que muito antes de se cogitar a existência deste princípio já se verificavam indícios de uma idéia de proporcionalidade ou proibição do excesso. Tanto é que são atribuídos a Blackstone e Beccaria alguns trabalhos no sentido da formulação desses conceitos. Apesar disso, tem-se que as origens do princípio remontamse à Antiguidade e não ao século XIX. De qualquer maneira, foi na Alemanha que essas idéias adquiriram fisionomia de um princípio jurídico consciente e autonomamente assumido (PASSAFARO JÚNIOR, 2009, p. 39).

Embora fosse possível identificar na doutrina alemã do segundo pós-guerra alguns relevantes estudos sobre a temática ${ }^{1}$, foi verdadeiramente a partir da jurisprudência do Tribunal Constitucional alemão que a proporcionalidade se sedimentou "como princípio implícito à Lei Fundamental de Bonn” (OLIVEIRA, 2007, p. 87). Nesse particular, faz-se importante trazer à baila as consideraçôes de Virgílio Afonso da Silva, tratando da proporcionalidade como regra hermenêutica a ser utilizada na ponderação de princípios, conforme o modelo de Alexy:

A regra da proporcionalidade no controle das leis restritivas de direitos fundamentais surgiu por desenvolvimento jurisprudencial do Tribunal Constitucional alemão e não é uma simples pauta que, vagamente, sugere que os atos estatais devem ser razoáveis, nem uma simples análise da relação meio-fim. Na forma desenvolvida pela jurisprudência constitucional alemã, tem ela uma estrutura racionalmente definida, com sub -elementos independentes - a análise da adequação, da necessidade e da proporcionalidade em sentido estrito - que são aplicados em uma ordem pré-definida, e que conferem à regra da proporcionalidade a individualidade que a diferencia, claramente, da mera exigência de razoabilidade (SILVA, 2002, p. 23-50).

A noção de proporcionalidade, em certo sentido, pode ser entendida como um aprimoramento da doutrina norte-americana da razoabilidade. Enquanto esta última estava ligada às ideias de "bom senso" e "justa medida", a proporcionalidade foi pensada e

1 Fábio de Oliveira ressalta que, "no ano de 1955, Rupprecht von Krauss publica a primeira monografia oferecida exclusivamente para a análise do postulado. Em 1961, Peter Lerche propóe a nomenclatura proibiçāo de excesso (Ubermassverbot)" (OLIVEIRA, 2007, p. 87). 
desenvolvida a partir de três sub elementos: a necessidade, a adequação e a proporcionalidade em sentido estrito. A teoria foi assim sintetizada por Luís Roberto Barroso:

[...] dele [princípio da proporcionalidade] se extraem os requisitos (a) da adequação, que exige que as medidas adotadas pelo Poder Público se mostrem aptas a atingir os objetivos pretendidos; (b) da necessidade ou exigibilidade, que impóem a verificação da inexistência de meio menos gravoso para atingimento dos fins visados; e (c) da proporcionalidade em sentido estrito, que é a ponderaçáo entre o ônus imposto e o benefício trazido, para constatar se é justificável a interferência na esfera dos direitos dos cidadãos (BARROSO, 2008, p. 229).

A "descoberta" do princípio da proporcionalidade enquanto norma constitucional não escrita ${ }^{2}$ pelo Tribunal Constitucional alemão foi central na disputa de poder entre o Judiciário e os outros dois poderes estatais (Executivo e Legislativo), pois viabilizou a intromissão dele, Judiciário, em assuntos que, historicamente, nunca foram de sua alçada. Mais ainda, possibilitou que uma norma jurídica produzida no poder Legislativo fosse rejeitada com base na aplicação dessa espécie de "fórmula mágica" capaz de aniquilar leis tidas por "inconstitucionais".

Mas essa "intromissão do Judiciário" - que, à primeira vista, parece ter sido realizada até mesmo de forma um pouco arbitrária - não pode ser entendida fora do contexto social e político pelo qual passava a Alemanha no segundo pós-guerra. Segundo Fábio de Oliveira, a ascensão do princípio da proporcionalidade teve bastante a ver com a necessidade identificada pelo Tribunal Constitucional alemão de superar as leis nazistas então em vigor:

A revolução progressista do princípio acontece após a II Guerra Mundial, impulsionada pela repulsa aos atos (inclusive legislativos) odiosos promovidos pelo nazi-fascismo. A proporcionalidade é alçada do Direito Administrativo para o Direito Constitucional. A Alemanha (ocidental) desempenha papel primaz no processo de constitucionalização e clarificação do princípio. Seu Tribunal Constitucional (Bundesverfassungsgeri$(h t)$, ao lado de portentosa produçáo doutrinária, se dedica arduamente, com base na Lei Fundamental de 23 de maio de 1949, ao reconhecimento normativo magno do paradigma da proporcionalidade (OLIVEIRA, 2007, p. 87).

De fato, com a derrota alemá na Segunda Guerra Mundial e a consequente queda do nazismo, o Tribunal Constitucional alemão se viu diante da necessidade de superar/invalidar todo um ordenamento jurídico produzido sobre uma lógica que já não mais atendia

2 Conforme explicado por Robert Alexy, a proporcionalidade "é deduzível do caráter princiopiológico das normas de direitos fundamentais” (ALEXY, 2008, p. 118). 
aos anseios sociais e políticos de então. Nesse sentido, pode-se afirmar que a adoção do princípio da proporcionalidade como parâmetro de controle de constitucionalidade de normas deve ser compreendida dentro desse contexto de reconstrução estatal pelo qual passava a Alemanha. Em outras palavras: o protagonismo assumido pelo Tribunal Constitucional alemão tinha por pano de fundo a necessidade social e política de romper com uma concepçáo política que admitia, em última análise, o assassinato de judeus mediante a utilização da câmara de gás e que, por isso mesmo, precisava ser expurgada de alguma maneira do Estado alemão.

\section{Teoria Impura do Direito: o Transplante Descontextualizado de Teorias Jurídicas}

O jusfilósofo colombiano Diego López Medina escreveu um livro intitulado Teoría Impura del Derecho, no qual desenvolveu a ideia de que o transplante descontextualizado de teorias jurídicas norte-americanas e europeias para a América Latina acabou provocando, historicamente, sensíveis distorçóes em clássicos institutos do Direito. A título de exemplo, López Medina relata que, enquanto na Europa e nos Estados Unidos as ideias de Hart e Dworkin sempre foram vistas como antagônicas, tendo gerado inclusive uma série de debates entre os dois autores, na Colômbia as duas teorias foram recepcionadas como se fossem aliadas em prol de uma crítica antiformalista ${ }^{3}$.

No primeiro capítulo de sua obra, López Medina chama a Teoria Clássica do Direito (v.g., Kelsen, Hart, Dworkin, etc.) de "Teoria Transnacional do Direito", ou TTD. Explica que a TTD, geralmente de origem europeia, é sempre produzida com pretensáo universalizante e, por isso mesmo, redigida "em abstrato" ou "em tese". Conclui dizendo que a TTD veicula "discursos abstratos de alcance global, que podem ser lidos, igualmente, por "pessoas do Japão, Gana, Grécia, Alemanha ou Colômbia” (MEDINA, 2013, p. 15).

Essa pretensão universalizante faz com que a TTD opere basicamente em dois âmbitos notoriamente distintos, conforme o local de sua produção. Nesse sentido, López Medina fala em duas importantes categorias, que são fundamentais para a compreensão de sua obra: os chamados "sítios de produção" e "sítios de recepção". Sobre os sítios de produção, destaca o autor:

3 Assinala López Medina: "La 'transplantabilidad' de Hart y Dworkin se basaba em la creencia que se trataba de teorías antiformalistas de validez universal porque sus conclusiones se extraían a partir de la naturaleza ubicua del lenguaje y la argumentación jurídica. Estas características, seguía el argumento, son compartidas universalmente por todos los sistemas jurídicos. Por estas razones, se argumenta, el formalismo jurídico estricto dominante em la región era uma teoria verificablemente errónea", sobretudo porque, "la obra de Hart era um buen ejemplo de um cierto tipo de teoria altamente formalista" (MEDINA, 2013, p. 5, 13). 
Um sítio de produção parece ser um meio especial onde se produzem discussôes justeóricas com altos níveis de influência transnacional sobre a natureza e as políticas do direito. Os sítios de produção estão usualmente afincados nos círculos intelectuais e instituiçóes acadêmicas de Estadosnação centrais e prestigiosos. Por conseguinte, os países centrais geram os produtos mais difundidos de TTD, produtos que com o tempo circulam pela periferia, para finalmente, vir a constituir globalmente o cânone normatizado do campo (MEDINA, 2013, p. 16). ${ }^{4}$

Em uma palavra: sítios de produçáo são os locais em que as Teorias Transnacionais do Direito (TTD), vale dizer, as teorias jurídicas dominantes e universalizantes são produzidas. Grandes exemplos de sítios de produção são Estados Unidos e Europa.

Quanto à outra categoria, os chamados "sítios de recepção", eis os comentários de Diego López Medina:

A outra face dos sitios de produção são os sitios de recepção. Dentro de um sítio de recepção, em geral, a justeoria ali produzida não tem a persuasão e a circulação ampla da TTD. Ao contrário, seria mais adequado falar de uma justeoria "local”, "regional”, "particular" ou "comparada" (MEDINA, 2013, p. 17).

Os sítios de recepção são característicos dos países periféricos ou semiperiféricos. As teorias originalmente ali produzidas muitas vezes são tratadas como inferiores, ou de segunda categoria, não tendo a mesma adesão das TTDs. Grande exemplo de sítio de produção é a América Latina.

O autor da Teoria Impura do Direito explica que, além de não possuírem tradição na produção de teorias jurídicas, os juristas acabam convivendo em ambiente hermenêuticos pobres nos sítios de recepção, porque "o autor e seus leitores periféricos compartilham muito pouca informação contextual acerca das estruturas jurídicas subjacentes ou as conjunturas intelectuais específicas nas quais nasceu o discurso justeórico” (MEDINA, 2013, p. $17-18)^{6}$.

4 Tradução livre de "Un sitio de producción parece ser un medio especial en donde se producen discusiones iusteóricas con altos niveles de influencia transnacional sobre la naturaleza y las políticas del derecho. Los sítios de produción están usualmente afincados em los círculos intelectuales e instituciones académicas de Estados-nación centrales y prestigiosos. Por conseguiente, los países centrales generan los produtos más difundidos de TTD, productos que con el tiempo circulan por la periferia, para finalmente, venir a constituir globalmente el canon normalizado del campo".

5 Traduçấo livre de: "La contracara de los sitios de producción son los sitios de recepción. Dentro de um sitio de recepcción, por lo general, la iusteoría producida allí ya no tiene la persuasividad y circulación amplia de la TTD, sino que, por el contrario, uno estaría tentado a hablar mejor de iusteoría 'local', 'regional', 'particular' o 'comparada'”.

6 Tradução livre de: "el autor y sus lectores periféricos comparten muy poca información contextual acerca de las estructuras subyacentes o las coyunturas políticas o intelectuales específicas em las que nació el discurso iusteórico". 
Assim é que, sem observar o contexto e a realidade na qual se deu a produção da justeoria, a sua reproduçâo acabou por promover inúmeras distorçóes nas teorias transplantadas, vide o exemplo já citado anteriormente da recepção das teorias de Hart e Dworkin na América Latina, especialmente na Colômbia.

Ao explicar esse fenômeno, Diego López Medina fala em tergiversação e em transmutação das ideias originais. Contudo, é importante destacar que o autor não pretende desmascarar esses supostos "equívocos", dizendo qual seria a interpretaçáo correta acerca das obras clássicas do Direito. Ao contrário, o que ele quer dizer é que essas "distorçôes" acabaram redundando na produção de uma doutrina jurídica latino americana própria, a partir dessa espécie de leitura atravessada de obras jurídicas estrangeiras. Nas palavras de López Medina,

na leitura tergiversada se abre a possibilidade de variação, adaptação e verdadeira criação. O estudo cuidadoso dessas transformações revela usos locais tão, ou até mesmo mais interessantes, que a história dessas mesmas ideias nos próprios sítios de produção (MEDINA, 2013, p. 35). ${ }^{7}$

Então, se utilizada como uma espécie de ponto de partida para o desenvolvimento das teorias jurídicas latino americanas, a leitura atravessada realizada nos sítios de recepção não seria algo negativo em si, justamente por visar obter respostas aos problemas reais vividos na periferia ou na semiperiferia; problemas que sequer poderiam ser pensados (e menos ainda respondidos) pelos autores situados nos sítios de produção. Em suma, desde que a tergiversação ou transmutação seja realizada com o escopo de adaptar ou contextualizar as teorias alienígenas às realidades locais, a impureza do Direito transplantado não seria algo negativo.

Contudo, essa leitura realizada por López Medina, no sentido de que a tergiversação e a transmutação relativamente às teorias jurídicas estrangeiras, podem ser vistas como algo positivo, dá margem a distorçôes que geram graves problemas de legitimidade institucional nos sítios de recepção. No Brasil, por exemplo, o transplante descontextualizado dos princípios da razoabilidade (Estados Unidos) e da proporcionalidade (Alemanha) acabou desvirtuando completamente ambos os institutos, na medida em que foram assimilados sobretudo para atender a um propósito ilegítimo e escamoteado pelo discurso oficial do controle de constitucionalidade de normas: longe de pretender garantir a supremacia da constituição, os princípios da razoabilidade e da proporcionalidade estão colocados à serviço do agigantamento do Judiciário em relação aos outros dois poderes estatais.

7 Traduçấo livre de "en la lectura tergiversada se abre la posibilidad de variación, adaptación y verdadera creación. El estudio cuidadoso de estas transformaciones revela usos locales tan, o incluso más interesantes, que la historia de esas mismas ideas en sitios de producción”. 


\section{Proporcionalidade Impura}

Ao contrário de Estados Unidos e Alemanha, o Brasil não possui qualquer tradição no manejo dos princípios da razoabilidade e da proporcionalidade. Não obstante, Gilmar Ferreira Mendes, Inocêncio Mártires Coelho e Paulo Gustavo Gonet Branco realizaram interessante trabalho de garimpagem na jurisprudência do Supremo Tribunal Federal em busca de alguma referência, ainda que indireta, aos aludidos princípios. Segundo eles, a primeira decisão que abordou a ideia de razoabilidade e proporcionalidade na Suprema Corte brasileira foi o Recurso Extraordinário no 18.331, de relatoria do Ministro Orozimbo Nonato. O trecho a seguir transcrito data de 1953:

O poder de taxar não pode chegar à desmedida do poder de destruir, uma vez que aquele somente pode ser exercido dentro dos limites que o tornem compatível com a liberdade de trabalho, de comércio e da indústria e com o direito de propriedade. É um poder, cujo exercício não deve ir até o abuso, o excesso, o desvio, sendo aplicável, ainda aqui, a doutrina fecunda do 'détournement de pouvoir'. Não há que estranhar a invocação dessa doutrina ao propósito da inconstitucionalidade, quando os julgados têm proclamado que o conflito entre a norma comum e o preceito da Lei Maior pode se acender náo somente considerando a letra do texto, como também, e principalmente, o espírito do dispositivo invocado (BRASÍlIA, STF, 1953 APUD MENDES; COELHO; BRANCO, 2007, p. 314).

Outra decisão citada pelos três autores foi a proferida no Habeas Corpus no 45.232, em que o Supremo Tribunal Federal declarou, em 1968, a inconstitucionalidade de norma da Lei de Segurança Nacional, "que obstava que o acusado de prática de crime contra a segurança nacional desempenhasse qualquer atividade profissional ou privada" (MENDES; COELHO; BRANCO, 2007, p. 314). Segundo eles,

O Supremo Tribunal reconheceu que a restrição se revelava desproporcional (exorbitância dos efeitos da condenação) e era, portanto, inconstitucional, por manifesta afronta ao próprio direito à vida em combinação com a cláusula de remissão referida (MENDES; COELHO; BRANCO, 2007, p. 315).

Náo se pode negar que as referências à noção de razoabilidade e proporcionalidade constantes nos votos acima citados são relevantes, muito embora não tenham sido desenvolvidas de forma autônoma, isto é, tenham vindo sempre fundamentadas em outras garantias constitucionais expressas, como o direito à propriedade no primeiro caso e o direito à vida no segundo. Entretanto, o fato é que ambos os julgados são apenas casos isolados na jurisprudência brasileira, náo representando o pensamento constitucional dominante da época em que foram proferidos. 
Foi apenas muitos anos depois, com a nomeação de ministros influenciados pelo Direito alemão, que as noçóes de razoabilidade e proporcionalidade começaram a se consolidar na jurisprudência do Supremo Tribunal Federal, predominantemente sob o nomen juris de "princípio da proporcionalidade". O principal nome desse período talvez seja o do próprio Ministro Gilmar Mendes, sob a influência de quem o STF proferiu aquela que é, até hoje, a mais famosa decisão consagradora do princípio da proporcionalidade: o caso da lei paranaense que exigia a pesagem de botijóes de gás na presença dos consumidores. Esclareça-se que, embora no momento do deferimento da medida cautelar Gilmar Mendes ainda não integrasse o Supremo Tribunal Federal na condição de Ministro, o então Relator, Ministro Sepúlveda Pertence, citou conferência proferida por Mendes no Congresso Luso-Brasileiro de Direito Constitucional ocorrido no ano de 1992, na cidade de Belo Horizonte. Eis a ementa da decisão:

Gas liquefeito de petroleo: lei estadual que determina a pesagem de botijoes entregues ou recebidos para substituição a vista do consumidor, com pagamento imediato de eventual diferença a menor: argüição de inconstitucionalidade fundada nos arts. 22, IV e VI (energia e metrologia), 24 e PARS., 25, PAR. 2., 238, além de violação ao princípio de proporcionalidade e razoabilidade das leis restritivas de direitos: plausibilidade jurídica da argüição que aconselha a suspensão cautelar da lei impugnada, a fim de evitar danos irreparaveis a economia do setor, no caso de vir a declarar-se a inconstitucionalidade: liminar deferida (BRASÍLIA, STF, 1993).

A grande questão é que, embora haja referência expressa ao princípio da proporcionalidade na decisão acima referida, o Supremo Tribunal Federal nitidamente não sabia manejar o instituto corretamente. Isso foi percebido por Virgílio Afonso da Silva em seu já conhecido texto $O$ proporcional e o razoável:

Sempre citada é a decisão liminar do STF que declarou inconstitucional a exigência de pesagem de botijóes de gás na presença do consumidor, instituída, no Paraná, por lei estadual. Não há como não se perguntar se os dispositivos considerados inconstitucionais - não só nessa, mas em várias outras decisôes em que se recorreu à regra da proporcionalidade foram considerados inadequados, desnecessários ou desproporcionais em sentido estrito. Não se sabe. E não há como se saber, visto que o STF não procedeu a nenhum desses exames de forma concreta e isolada. E se não os realizou, não foi aplicada a regra da proporcionalidade (SILVA, 2002, p. 23-50).

Realmente, a impressão que fica é que, no caso do botijão de gás, o Supremo Tribunal Federal não encontrou nenhum outro parâmetro de controle de constitucionalidade para retirar do ordenamento paranaense uma lei considerada inoportuna naquele momento histórico. Sem outra opção plausível, o STF lançou mão do princípio 
(constitucional?) da proporcionalidade para corrigir uma decisão política que ele considerou equivocada. O que se nota, já de saída, é que, ao contrário de Estados Unidos e Alemanha, a Suprema Corte brasileira optou por adentrar no mérito legislativo em caso de pouca ou quase nenhuma repercussão social, buscando auto-afirmaçáo dentro do cenário político de tensão entre os três poderes.

De lá pra cá, mesmo depois de alguma evolução doutrinária sobre o tema ${ }^{8}$, o Supremo Tribunal Federal aprofundou a técnica sem mudar a mais nefasta consequência de seus votos embasados na proporcionalidade: a ingerência sobre os outros poderes constituídos.

$\mathrm{Na}$ ADI no 4.955/CE, o Supremo adentrou em matéria cuja competência é inequivocamente do Legislativo ao definir que "obstar a venda de produtos de conveniência em farmácias e drogarias seria, em última análise, impor restrição ao livre exercício da atividade comercial, a qual violaria o princípio da proporcionalidade, por não ser adequada, necessária nem proporcional ao fim almejado, qual seja, a proteção e a defesa da saúde" (BRASÍLIA, STF, 2014b). No Recurso Extraordinário no 365.368/SC, o Supremo adentrou em matéria de competência organizacional do Poder Legislativo municipal, determinando que "Cabe ao Poder Judiciário verificar a regularidade dos atos normativos e de administração do Poder Público em relação às causas, aos motivos e à finalidade que os ensejam", complementando que "Pelo princípio da proporcionalidade, há que ser resguardada correlação entre o número de cargos efetivos e em comissão, de maneira que exista estrutura para atuação do Poder Legislativo local" (BRASÍLIA, STF, 2007). Por fim, no Recurso Extraordinário no 580.642/PR, reafirmou sua supremacia em relação ao Executivo ao consignar que " $\mathrm{O}$ controle judicial de atos administrativos tidos por ilegais ou abusivos não ofende o princípio da separação dos Poderes, inclusive quando a análise é feita à luz dos princípios da proporcionalidade e da razoabilidade" (BRASÍLIA, STF, 2014a).

Em suma, o órgão de cúpula do Poder Judiciário brasileiro encontrou na fórmula da proporcionalidade desenvolvida pelo Tribunal Constitucional alemão um cheque em branco para a tomada de decisóes políticas sobre os mais diversos assuntos do dia-a-dia, por mais corriqueiros e irrelevantes que eles possam parecer. Mais ainda: aderindo ao referido princípio as noçôes de "bom sendo" e "justa medida" inerentes à de razoabilidade norte-americana, e acrescentando uma pitada de brasilidade, o Supremo Tribunal Federal criou e legitimou essa espécie de proporcionalidade impura, cuja incidência atualmente parece carecer apenas do subjetivismo e da criatividade do julgador.

8 Além do excelente trabalho de Virgílio Afonso da Silva, já citado, é preciso fazer menção à obra Teoria dos Princípios, de Humberto Ávila, no qual o jurista gaúcho defende que a proporcionalidade não é princípio, mas, sim, postulado jurídico (ẤVILA, 2012). 


\section{Conclusões}

Sob o ponto de vista histórico, é possível dizer que a razoabilidade norte-americana configurou-se a partir dos processos de luta que culminaram na realizaçáo dos anseios da sociedade estadunidense. Com o fito de promover materialmente a justiça nos casos submetidos ao seu julgamento, sem romper com a ordem constitucional vigente, a Suprema Corte se viu eventualmente diante da necessidade de desdobrar a cláusula do devido processo legal, consagrando a sua dimensão material, o devido processo legal substantivo, por meio do princípio da razoabilidade.

De igual modo, o Tribunal Constitucional alemão, ao desenvolver a noção de proporcionalidade, tinha diante de si um contexto no qual era necessário superar um ordenamento jurídico ultrapassado, que disseminava ideais nazistas não mais inseridos na realidade alemã do segundo pós-guerra. É possível afirmar, inclusive, que esse movimento ativista do Judiciário alemão foi não apenas legítimo, mas também necessário e essencial, porque veio salvar, ou libertar, o povo alemão de seus fantasmas, materializados em suas próprias leis.

Quando o Brasil promoveu a assimilação dos aludidos princípios por meio de sua doutrina e de sua jurisprudência, predominantemente sob o nomen juris de "princípio da proporcionalidade", advinda da influência do Direito alemão, o contexto jurídico em que razoabilidade e proporcionalidade se desenvolveram foi completamente desconsiderado ou, como prefere o colombiano López Medina, transmutado, tergiversado. É como se os estudiosos brasileiros do Direito, muitos deles magistrados com pós-graduação no exterior, intuindo o impacto que o transplante da proporcionalidade provocaria na tensão entre os poderes estatais, tivessem descoberto uma "fórmula mágica" (adequação, necessidade e proporcionalidade em sentido estrito) apta a legitimar decisóes embasadas em nada mais do que o senso comum de justiça ou, o que é pior, na subjetividade do julgador.

E qual o grande símbolo dessas decisões embasadas no senso comum subjetivo de justiça do julgador? A decisão proferida na Ação Direta de Inconstitucionalidade no 855/ $\mathrm{PR}$, em que se discutiu apaixonadamente a possibilidade ou não de o poder Legislativo obrigar as empresas que comercializavam botijôes de gás a portar uma balança em seus caminhóes, viabilizando a pesagem do produto por cada um dos consumidores interessados. Isto mesmo: enquanto nos Estados Unidos os magistrados da Suprema Corte utilizavam o princípio da razoabilidade para garantir direitos fundamentais, discutindo, por exemplo, a criminalização do uso da pílula anticoncepcional ou do aborto, e na Alemanha o Tribunal Constitucional alemão utilizava o princípio da proporcionalidade para extirpar do ordenamento leis de inspiração nazista que oprimiam o seu povo, no Brasil o Supremo Tribunal Federal utilizou-se dos dois princípios para declarar a inconstitucionalidade de uma norma estadual completamente irrelevante, mas que, no fundo, tinha o nobre propósito de garantir os direitos dos consumidores, em atenção à nova ordem constitucional. 
Náo deixa de ser irônico que o tema do gás estivesse presente tanto em decisóes do Tribunal Constitucional alemão quanto em decisóes do Supremo Tribunal Federal brasileiro: na Alemanha a proporcionalidade foi utilizada para afastar normas cuja lógica permitia o assassinato de judeus nos campos de concentração, por meio de câmaras de gás; no Brasil a proporcionalidade foi utilizada em prol das empresas que queriam vender botijóes de gás mais leves do que o anunciado a seus consumidores.

Bem ou mal, o fato é que o desastrado transplante do princípio da proporcionalidade pelo Direito brasileiro acabou por transformar o instituto numa verdadeira proporcionalidade impura que, longe de revelar preocupação com a supremacia da constituição ou a garantia de direitos fundamentais, serve sobretudo para legitimar a declaração de inconstitucionalidade de normas que, em verdade, não são inconstitucionais. Em última análise, o transplante do princípio da proporcionalidade serviu mesmo para garantir ao Judiciário a supremacia em relação aos outros dois poderes estatais, que acabam ficando à mercê do subjetivismo dos julgadores. Afinal, não é demasiado afirmar, com Carl Schmitt, que quem tem o poder de dar a última palavra no que se refere à constitucionalidade das leis, posiciona-se inegavelmente na condição de soberano da nação.

\section{Referências}

ALEXY, Robert. Teoria dos direitos fundamentais. São Paulo: Malheiros, 2008.

ÁVILA, Humberto. Teoria dos princípios: da definição à aplicação dos princípios jurídicos. 13. ed. São Paulo: Malheiros, 2012.

BARROSO, Luís Roberto. Interpretação e Aplicação da Constituição. 6. ed. São Paulo: Saraiva, 2008.

BRASÍLIA, Supremo Tribunal Federal, RE no 18.331, Relator: Min. Orozimbo Nonato, 1953.

. ADI-MC no 855, Relator: Min. Sepúlveda Pertence, 1993.

. RE-AgR no 365.368, Relator: Min. Ricardo Lewandowski, 2007.

. RE-AgR 580.642, Relator: Min. Roberto Barroso, 2014.

. ADI 4.955, Relator: Min. Dias Toffoli, 2014.

CUNHA JÚNIOR, Dirley da. Curso de Direito Constitucional. 2. ed. Salvador: JusPodivm, 2008.

FLORES, Joaquín Herrera. A (re)invenção dos Direitos Humanos. Florianópolis: Fundação Boiteux, 2009.

KELSEN, Hans. Jurisdição constitucional. São Paulo: Martins Fontes, 2003. 
MEDINA, Diego Eduardo López. Teoría Impura del Derecho: la transformación de la cultura jurídica latinoamericana. Bogotá: Legis, 2013.

MENDES, Gilmar Ferreira, COELHO, Inocêncio Mártires e BRANCO, Paulo Gustavo Gonet. Curso de Direito Constitucional. São Paulo: Saraiva, 2007.

OliveIRA, Fábio de. Por uma Teoria dos Princípios: O princípio Constitucional da Razoabilidade. 2. ed. Rio de Janeiro: Lumen Juris, 2007.

PASSAFARO JÚNIOR, Leonardo Luiz. O princípio da proibição do excesso nas afetaçôes dos direitos fundamentais sociais. Lisboa: Universidade de Lisboa, 2009.

SCHMITT, Carl. O guardiáo da constituiçáa. Belo Horizonte: Del Rey, 2007.

SILVA, Virgílio Afonso da. O proporcional e o razoável. In.: Revista dos Tribunais. V. 798, p. 23-50. 